\title{
A Rapid Sensitive Assay for Phosphatidate Phosphohydrolase
}

\author{
J. E. Bleasdale, C. S. Davis, A. K. Hajra, and B. W. Agranoff \\ Neuroscience Laboratory, Mental Health Research Institute and Department of Biological \\ Chemistry, The University of Michigan, Ann Arbor. Michigan 48109
}

Received June 16, 1977; accepted January 13, 1978

\begin{abstract}
For a purified preparation of the soluble form of phosphatidate phosphohydrolase (EC 3.1.3.4) from guinea pig cerebral cortex, 1-O-alkyl-racglycerol 3-phosphate was found to be accepted as a substrate. This substrate analog was tritium-labeled in order to serve in a rapid sensitive assay for the enzyme, in which labeled 1-alkyl glycerol is released. Heat denaturation and enzyme activity dependence on $\mathrm{pH}$ indicated that 1-O-alkyl-rac-glycerol 3phosphate phosphohydrolase and phosphatidate phosphohydrolase activities in the preparation are attributable to the same enzyme. 1-O-Alkyl-rac-glycerol 3phosphate was hydrolyzed with a $V_{\max }$ of $1.7 \mathrm{nmol} \mathrm{min}^{-1} \mathrm{mg}^{-1}$ of protein and a $K_{m}$ of $270 \mu \mathrm{M}$.
\end{abstract}

Phosphatidate phosphohydrolase (EC 3.1.3.4) catalyzes the production of 1,2-diacyl-sn-glycerol from phosphatidic acid and consequently occupies a possible branch point between neutral lipid and CDPdiglyceride pathways on the one hand and CDP-choline- and CDPethanolamine-linked phospholipid biosynthesis on the other. In rat liver there is evidence that this enzyme may be rate limiting in the synthesis of both neutral lipid (1) and glycerophospholipid (2). In the same tissue, the activity of phosphatidate phosphohydrolase has been shown to be changed by a variety of treatments, including starvation (2), carbohydrate-rich diets (3), subtotal hepatectomy (4), and drugs (5). Triiodothyronine affects phosphatidate phosphohydrolase activity in rabbit heart (6), and, in synaptosomes prepared from guinea pig cerebral cortex, this enzymatic step appears to be stimulated by acetylcholine (7). Despite considerable interest in phosphatidate phosphohydrolase, its measurement has not been straightforward. Conventional assays are restricted by several factors, including the relative insolubility of phosphatidic acid, the insensitivity of methods relying upon measurement of inorganic phosphate released, and the limitations of ${ }^{32} \mathrm{P}$-labeled substrate relating to the short half-life of the isotope. We describe here the synthesis of $1-O$-hexadecyl-rac $-\left[2-{ }^{3} \mathrm{H}\right]$ glycerol 3-phosphate and its applicability as a water-soluble substrate analog of phosphatidic acid for the assay of phosphatidate phosphohydrolase. 


\section{MATERIALS AND METHODS}

Acid phosphatase (potato B grade) was obtained from Calbiochem, Los Angeles, Calif. as was Bio-Rad AGI-X2, 200-400 mesh. Chimyl alcohol, hexadecyl iodide, and $p$-nitrophenylphosphate were from Sigma Chemical Co., St. Louis, Mo. Sodium boro $\left[{ }^{3} \mathrm{H}\right]$ hydride $(8 \mathrm{Ci} / \mathrm{mmol})$ was supplied by Amersham/Searle Corp., Arlington Heights, Ill., and $\left.{ }^{32} \mathrm{P}\right]-$ orthophosphoric acid (carrier-free, in $0.02 \mathrm{M} \mathrm{HCl}$ ) was obtained from New England Nuclear, Boston, Mass. Other chemicals were of commercially available reagent grade.

\section{Purification of Phosphatidate Phosphohydrolase (EC 3.1.3.4)}

A 20-fold purified preparation of the soluble form of phosphatidate phosphohydrolase from guinea pig cerebral cortex was used in this study. An ammonium sulfate-precipitable fraction $(0-50 \%)$ of a $100,000 \mathrm{~g}$ supernatant was subjected to Sepharose-4B chromatography. Details.of the purification and characterization of the enzyme are presented elsewhere (8).

\section{Preparation of 1-O-Hexadecyl rac- $\left[2-{ }^{3} \mathrm{H}\right]$ Glycerol 3-Phosphate}

1-O-Hexadecyl dihydroxyacetone 3-phosphate was synthesized as outlined by Hajra (9), except the intermediate $2-O$-hexadecyl glycolic acid was synthesized by refluxing hexadecyl iodide, ethyl glycolate, and silver oxide in a molar ratio of $1 / 2.5 / 1.5$ in xylene for $15 \mathrm{hr}$. 1-O-Hexadecyl rac- $\left[2-{ }^{3} \mathrm{H}\right]$ glycerol 3-phosphate (1-alkyl G3P) was prepared from 1-Ohexadecyl dihydroxyacetone phosphate by reducing with $\left[{ }^{3} \mathrm{H}\right] \mathrm{NaBH}_{4}(10)$. The product was purified on a Unisil column (Clarkson Chemical Co., Inc., Williamsport, Pa.) and eluted with 3 column volumes of chloroform to remove nonpolar contaminants followed by 5 column volumes of chloroform/methanol (4/1) to elute the 1-alkyl G3P. Purity of the substrate was assessed by thin-layer chromatography on silica-gel $G$ plates (Uniplate, Analtech Inc., Newark, Del.) developed in chloroform/ methanol/acetic acid/water (100/40/12/4) followed by fluorography (11). Phosphate content was determined by the method of Ames and Dubin (12), and radioactivity was measured in an ethanol-toluene scintillant $(200 \mathrm{ml}$ of ethanol, $3640 \mathrm{ml}$ of toluene, $20 \mathrm{~g}$ of PPO, and $0.4 \mathrm{~g}$ of POPOP). The purified substrate was stored in chloroform/methanol $(2 / 1)$ at $-20^{\circ} \mathrm{C}$.

\section{Assay of Phosphatidate Phosphohydrolase}

\section{Membrane-bound Phosphatidic Acid as Substrate}

Glycerol 3-[32 P]phosphate was prepared enzymatically by phosphorylation of glycerol with $\left[\gamma^{32} \mathrm{P}\right] \mathrm{ATP}(8,13)$. Membrane-bound $\left[{ }^{32} \mathrm{P}\right]$ phosphatidic acid (8) was then synthesized by incubating guinea pig liver microsomes with $s n$-glycerol 3-[ $\left.{ }^{32} \mathrm{P}\right]$ phosphate. After the microsomes were 
heated for $30 \mathrm{~min}$ in a boiling water bath, they were dialyzed overnight against water. Not less than $98 \%$ of incorporated radioactivity was recovered in phosphatidic acid. Phosphatidate phosphohydrolase activity was assayed by measuring release of $\left[{ }^{32} \mathrm{P}\right]$ orthophosphate from the heatdenatured microsomes (8).

\section{1-O-Hexadecyl rac-[2- $\left.{ }^{3} \mathrm{H}\right]$ Glycerol 3-Phosphate as Substrate}

1-Alkyl G3P was dissolved in $100 \mathrm{~mm}$ Tris-maleate buffer ( $\mathrm{pH} 7.2)$ by warming to $40^{\circ} \mathrm{C}$ and sonicating briefly (three times for $20 \mathrm{sec}$ in a Bransonic 2, 60Hz-40W Heat Systems-Ultrasonics Inc., Plainview, N. Y.). Incubations were at $37^{\circ} \mathrm{C}$ in a shaking water bath and contained (in a final volume of $100 \mu$ l) $10 \mu \mathrm{mol}$ of Tris-maleate buffer $(\mathrm{pH} \mathrm{7.2),50 \textrm {nmol }}$ of 1-alkyl G3P (approx $20 \mu \mathrm{Ci} / \mu \mathrm{mol}$ ), and purified phosphatidate phosphohydrolase (5-100 $\mu \mathrm{g}$ of protein). Reactions were initiated by addition of substrate. Three different procedures were used to terminate reactions and measure the product formed.

Assay $A$. The reaction was stopped by adding $1.2 \mathrm{ml}$ of chloroform/ methanol (1/2) followed by $0.6 \mathrm{ml}$ of $50 \mathrm{~mm} \mathrm{NaOH}$ and $0.4 \mathrm{ml}$ of chloroform. After vortex mixing, two phases were separated by brief centrifugation $(700 \mathrm{~g}$ for $5 \mathrm{~min}$ ), and a $600-\mu \mathrm{l}$ sample of the lower phase was washed twice with $2 \mathrm{ml}$ of the equilibrated upper phase. A $300-\mu l$ sample of the washed lower phase was dried in a scintillation vial, and $10 \mathrm{ml}$ of ethanol-toluene scintillant were added.

Assay B. After incubation, each sample received $1.4 \mathrm{ml}$ of ice-cold $20 \mathrm{~mm} \mathrm{NaOH}$ and $2.0 \mathrm{ml}$ of ice-cold diethyl ether/ethanol (3/1). After vortex mixing $(10 \mathrm{sec})$ and centrifugation $(700 \mathrm{~g}$ for $1 \mathrm{~min})$, a sample $(1.0 \mathrm{ml})$ of the upper phase was taken to dryness, and radioactivity was determined as described above.

Assay $C$. To terminate the reactions, $100 \mathrm{mg}$ of Bio-Rad AG1-X2, $200-400$ mesh $\left(\mathrm{OH}^{-}\right.$form) in $1.5 \mathrm{ml}$ of $90 \%$ ethanol at $4^{\circ} \mathrm{C}$ was added. After thorough vortex mixing, samples were centrifuged $(700 \mathrm{~g}$ for 10 $\mathrm{min}$ ), and $1.0 \mathrm{ml}$ of each supernatant was added to $9.0 \mathrm{ml}$ of ethanoltoluene scintillant containing $10 \%(\mathrm{v} / \mathrm{v})$ Triton $\mathrm{X}-100$.

\section{Other Determinations}

Acid phosphatase was assayed in sodium citrate buffer ( $100 \mathrm{mM}, \mathrm{pH} 5.6)$ using $p$-nitrophenylphosphate as substrate (14). Protein was determined by the method of Lowry et al. (15) with bovine serum albumin (Pentex, Miles Labs. Inc., Elkhart, Ind.) as standard.

\section{RESULTS}

\section{Characterization of Assay Conditions}

The standard assay mixture consisted of $100 \mathrm{~mm}$ Tris-maleate buffer

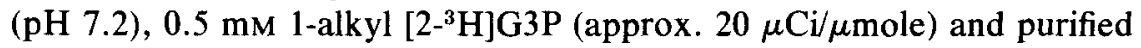
phosphatidate phosphohydrolase in a total volume of $100 \mu \mathrm{l}$. 
Inclusion of EDTA ( $5 \mathrm{mM}$ ) in the assay medium did not affect 1-alkyl G3P phosphohydrolase activity in this preparation but did stimulate cruder preparations. With $5 \mathrm{mM} \mathrm{MgCl}_{2}$, an inhibition of approximately $80 \%$ was obtained. Under the same conditions, hydrolysis of membranebound phosphatidate was inhibited about $65 \%(8)$. When $5 \mathrm{mg} / \mathrm{ml}$ bovine serum albumin (BSA) was added to the assay medium, an inhibition of about $20 \%$ was observed. At high dilutions of enzyme, however, denaturation occurred, and this could be prevented by the above concentration of BSA. The effectiveness of the three assay procedures for separating product and unused substrate was assessed by measuring the percentage recovery of product and the percentage of added substrate (1-alkyl G3P) extracted with the product. From six determinations, the values (means \pm SD) for percentage of product and substrate were found to be as follows: Procedure A, 96.7 \pm 0.9 and $0.41 \pm 0.01$; Procedure B, 100.4 \pm 1.4 and $0.65 \pm 0.01$; Procedure $C, 95.8 \pm 2.2$ and $2.05 \pm 0.09$. While Procedure $\mathrm{C}$ was the most rapid, it gave higher blank values and could not be used at enzyme concentrations greater than $1 \mathrm{mg}$ of protein $/ \mathrm{ml}$ without first deproteinizing the sample. The data presented below were obtained using Procedure B. When the products of the enzyme reaction were subjected to thin-layer chromatography on silica gel plates (silica gel 60, 0.25-mm layer, Brinkmann Instruments, Inc., Des Plaines, Ill.) developed in chloroform/methanol/acetic acid/water $(100 / 40 / 12 / 4$ by vol $)$, more than $95 \%$ of the applied radioactivity was recovered in a spot comigrating with chimyl alcohol.

The assay procedure gave linear rates of hydrolysis with increasing time and enzyme concentration (Fig. 1). Assays were routinely performed for $30 \mathrm{~min}$ with $0.8 \mathrm{mg}$ of protein $/ \mathrm{ml}$.

\section{Characterization of 1-Alkyl G3P Phosphohydrolase Activity}

Several criteria indicated that the enzyme activity measured by the described assay was attributable to phosphatidate phosphohydrolase. First of all, the possibility that the hydrolysis was catalyzed by acid phosphatase seems unlikely since the enzyme preparation would not hydrolyze $p$ -

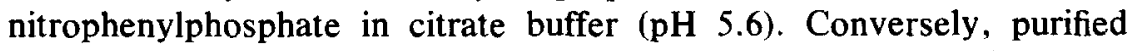
acid phosphatase from potato did not hydrolyze 1-alkyl G3P. Furthermore, the observed $\mathrm{pH}$ optimum of 7.2 (Fig. 2) tends to rule out both acid and alkaline phosphatases as the enzyme responsible for the observed phosphohydrolase activity. The $\mathrm{pH}$ profile closely resembled that obtained when membrane-bound phosphatidic acid was used as substrate. The apparent small difference in $\mathrm{pH}$ optima is not surprising since the physical states of the two substrates are quite different. In other studies with the membrane-bound substrate, the $\mathrm{pH}$ profile was found to be somewhat dependent upon the source of microsomes used for preparation of the substrate $(8)$.

Enzyme activity was rapidly lost when the preparation was heated at 


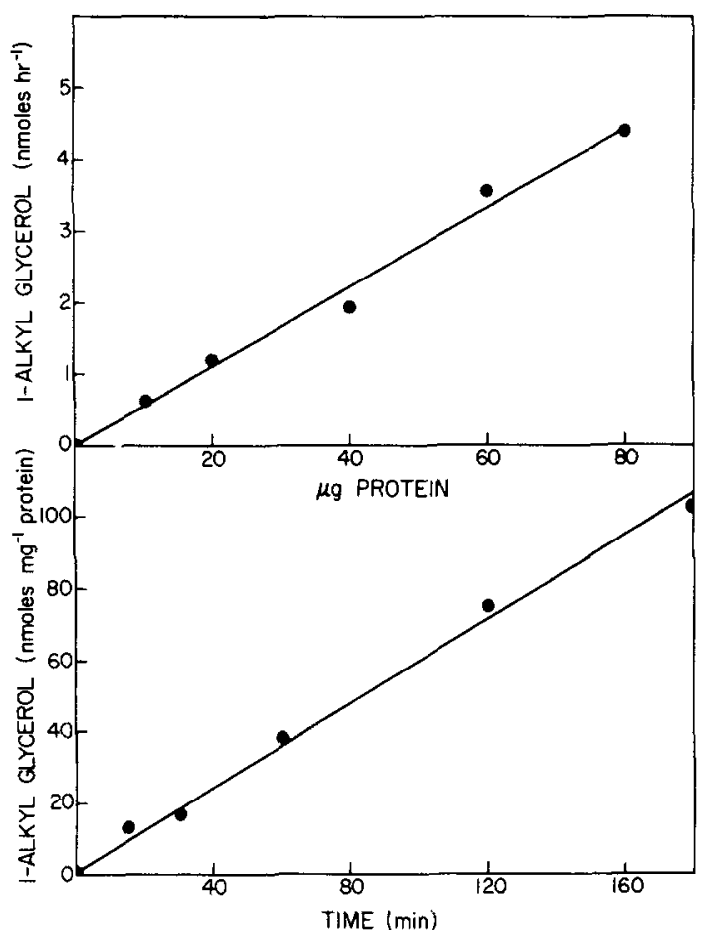

FIG. 1. Linearity of assay with protein concentration and time. Assay conditions were as described in the text, and Procedure $B$ was used to measure the product formed (mean of six determinations).

$70^{\circ} \mathrm{C}$. The loss of 1-alkyl G3P phosphohydrolase activity closely paralleled the disappearance of phosphatidate phosphohydrolase activity (Fig. 3). When the data are expressed as log percentage activity remaining against time (Fig. 3, inset), the points fall on a straight line indicating a firstorder reaction; this suggests that both phosphohydrolase activities can be ascribed to a single enzyme.

Figure 4 shows the dependence of 1-alkyl G3P phosphohydrolase activity on 1-alkyl G3P concentration. The data shown give a $K_{m}$ of 270

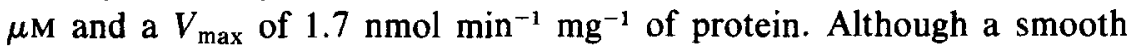
curve has been used to fit the data, a break in the curve between 200 and $400 \mu \mathrm{M}$ cannot be ruled out. In this range, the micellar form of the substrate would begin to predominate (the critical micellar concentration of hexadecyl dihydroxyacetone phosphate has been estimated to be greater than $150 \mu \mathrm{M})(17)$. When phosphatidate phosphohydrolase activity was measured using membrane-bound phosphatidate, a $K_{m}$ of 25

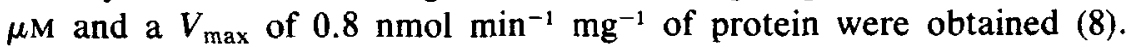
Experiments in which the release of $\left[{ }^{32} \mathrm{P}\right]$ orthophosphate from ${ }^{32} \mathrm{P}$-labeled membrane-bound phosphatidic acid was measured in the presence of unlabeled 1-alkyl G3P suggested competitive inhibition (18). 


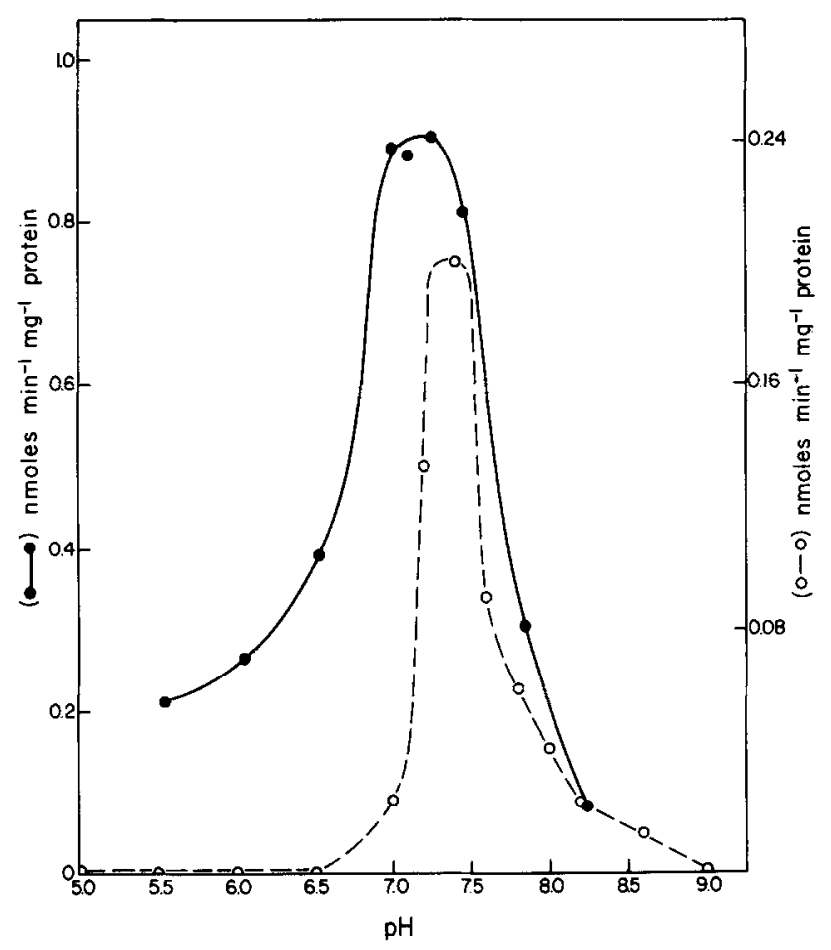

Fig. 2. The dependence of phosphatidate phosphohydrolase activity on pH using (O) membrane-bound [32 P]phosphatidic acid or (O) 1-alkyl [2- $\left.{ }^{3} \mathrm{H}\right]-\mathrm{G} 3 \mathrm{P}$ as substrate. With 1-alkyl $\left[2-{ }^{3} \mathrm{H}\right] \mathrm{G} 3 \mathrm{P}$ the buffer was $100 \mathrm{~mm}$ Tris-maleate $(25)$, and the buffer for the membranebound substrate was $50 \mathrm{~mm}$ Tris-maleate $(\mathrm{pH} 5.0$ to 7.5$)$ and $50 \mathrm{~mm}$ Tris $-\mathrm{HCl}(\mathrm{pH} 7.0$ to 9.0$)(8)$. Incubations were with $80 \mu \mathrm{g}$ of protein, and heated-enzyme $\left(10 \mathrm{~min}\right.$ at $70^{\circ} \mathrm{C}$ ) blank values were determined at each $\mathrm{pH}$ value (mean of three experiments).

\section{DISCUSSION}

The assays thus far employed for determining phosphatidate phosphohydrolase activity involve measuring either the release of inorganic phosphate from aqueous dispersions of phosphatidic acid (19), the release of $\left[{ }^{32} \mathrm{P}\right]$ orthophosphate from heat-denatured microsomes containing $\left[{ }^{32} \mathrm{P}\right]$ phosphatidic acid $(8)$, or the production of $\left[{ }^{14} \mathrm{C}\right]$ palmitate-containing neutral lipid (presumably diglyceride) from denatured microsomes containing glycerolipid labeled with $\left[{ }^{14} \mathrm{C}\right]$ palmitate (20). None of these methods is completely satisfactory. The first method lacks sensitivity, while the preparation of membrane-bound phosphate-labeled phosphatidate is inconvenient because the relatively short half-life of ${ }^{32} \mathrm{P}$ (and ${ }^{33} \mathrm{P}$ as well) prohibits storage of substrates for long periods. Assays employing $\left[{ }^{14} \mathrm{C}\right]$ palmitate-labeled microsomes lack specificity, since up to $25 \%$ of the incorporated isotope is in glycerolipids other than phosphatidic acid (4). While this ${ }^{14} \mathrm{C}$-labeled substrate can be stored for long 




Fig. 3. Heat denaturation of phosphatidate phosphohydrolase using $(O)$ membrane-bound $\left[{ }^{32} \mathrm{P}\right]$ phosphatidic acid and $(-)$ 1-alkyl $\left[2{ }^{3} \mathrm{H}\right]-\mathrm{G} 3 \mathrm{P}$ as substrate (mean of three experiments).

periods, it is destroyed by repeated freeze-thawing (4). In all these assay procedures, the substrate is poorly soluble, and the enzyme kinetics obtained from such suspensions are often difficult to interpret.

The substrate analog described here (1-O $O$-hexadecyl-rac- $\left[2-{ }^{3} \mathrm{H}\right]$ glycerol 3-phosphate) can be synthesized at high specific radioactivity and has been stored at $-20^{\circ} \mathrm{C}$ in chloroform/methanol (2/1) for 3 months without detriment. Since it was necessary to raise the $\mathrm{pH}$ above 9 (16) for effective partitioning of substrate and product (Assays $\mathrm{A}$ and $\mathrm{B}$ ), the alkali-labile analog 1-acyl G3P, could not be used. In experiments (not shown) where 1 -acyl glycerol $3-\left[{ }^{32} \mathrm{P}\right]$ phosphate was used as substrate and release of [32P]orthophosphate was measured, a $K_{m}$ value was obtained close to that for 1-alkyl G3P. The affinity of the enzyme for 1-alkyl G3P is much less than for membrane-bound phosphatidate, but the maximum reaction velocity is considerably higher for 1-alkyl G3P. 1-Acyl G3P (lysophosphatidate) has previously been reported as a good substrate for phosphatidate phosphohydrolase from $E$. coli (21), rat liver microsomes (22), and mitochondria from hamster intestinal mucosa (23). Using a purified phosphatidate phosphohydrolase preparation from rat liver as described by Lamb and Fallon (1), we found 1-alkyl G3P to be hydrolyzed at a faster rate than phosphatidate. Phosphatidate phosphohydrolase occurs in a membrane-bound form in human amniotic fluid (24), and in this instance both the affinity and $V_{\max }$ are higher for 1- 


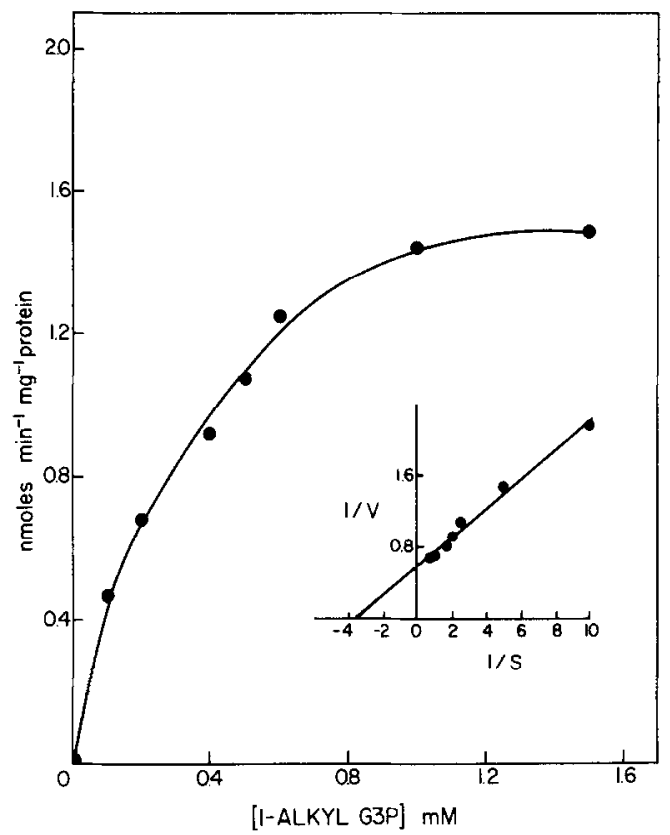

FIG. 4. The effect of 1-alkyl G3P concentration on phosphatidate phosphohydrolase activity. Varying amounts of $2.0 \mathrm{~mm} 1$-alkyl G3P in $100 \mathrm{~mm}$ Tris-maleate ( $\mathrm{pH} \mathrm{7.2)}$ were added to each incubation. Reactions were started with the addition of enzyme ( $80 \mu \mathrm{g}$ of protein) and terminated as described in the text (Procedure B) after $30 \mathrm{~min}$ at $37^{\circ} \mathrm{C}$. A reciprocal plot of the data (inset) yields a $K_{m}$ value of $270 \mu \mathrm{M}$ and a $V_{\max }$ of $1.68 \mathrm{nmol} \mathrm{min} \mathrm{mg}^{-1} \mathrm{mg}^{-1}$ of protein.

alkyl G3P than for aqueous dispersions of phosphatidic acid (25). While lysophosphatidic acid should not be ruled out as a physiological substrate, part of the observed high $V_{\max }$ may be due simply to 1-alkyl G3P being more soluble than phosphatidic acid. When considering membranebound forms of phosphatidate phosphohydrolase, the efficacy of lysosubstrates may be related to their detergent properties. It should be noted that other considerations argue in favor of the conclusion that hydrolysis of phosphatidic acid and the model substrate are catalyzed by the same enzyme. In analogous studies, similar effects from $\mathrm{Mg}$, EDTA, and albumin were found not only for the brain enzyme (8) but also for the phosphohydrolase in amniotic fluid $(25,26)$. In amniotic fluid, physiological variation in activity as related to fetal lung maturity shows good correspondence between the two substrates.

The sensitivity of the new assay is limited only by the specific radioactivity of the $\left[{ }^{3} \mathrm{H}\right] \mathrm{NaBH}_{4}$ used to prepare the synthetic substrate. Since the reagent is routinely available at specific radioactivities greater than $10 \mathrm{Ci} / \mathrm{mmol}$, even greater sensitivity than is described here should be attainable if desired. 


\section{ACKNOWLEDGMENTS}

We wish to thank Mr. E. Seguin for assistance in preparing the substrate analog. This work was supported by NIH Grant NS03101.

\section{REFERENCES}

1. Lamb, R. G., and Fallon, H. J. (1974) Biochim. Biophys. Acta 348, 166-178.

2. Vavrecka, M., Mitchell, M. P., and Hübscher, G. (1969) Biochem. J. 115, 139-145.

3. Lamb, R. G., and Fallon, H. J. (1974) Biochim. Biophys. Acta 348, 179-188.

4. Mangiapane, E. H., Lloyd-Davies, K. A., and Brindley, D. N. (1973) Biochem. J. 134, 103-112.

5. Sturton, R. G., and Brindley, D. N. (1977) Biochem. J. 162, 25-32.

6. Kako, K. J., and Patterson, D. S. (1975) Biochem. J. 152, 313-323.

7. Schacht, J., and Agranoff, B. W. (1974) J. Biol. Chem. 249, 1551-1557.

8. Davis, C. S. (1976) Ph.D. Thesis, University of Michigan.

9. Hajra, A. K. (1970) Biochem. Biophys. Res. Commun. 39, 1037-1044.

10. LaBelle, E. F., and Hajra, A. K. (1974) J. Biol. Chem. 249, 6936-6944.

11. Randerath, K. (1970) Anal. Biochem. 34, 188-205.

12. Ames, B. N., and Dubin, D. T. (1960) J. Biol. Chem. 235, 769-775.

13. Glynn, I. M., and Chappell, J. B. (1964) Biochem. J. 90, 147-149.

14. Bergmeyer, H. U. (1965) in Methods of Enzymatic Analysis, p. 783, Academic Press, New York, second printing, revised.

15. Lowry, O. H., Rosebrough, N. J., Farr, A. L., and Randall, R. J. (1951) J. Biol. Chem. 193, 265-275.

16. Hajra, A. K. (1974) Lipids 9, 502-505.

17. LaBelle, E. F. (1974) Ph.D. Thesis, p. 180, University of Michigan.

18. Dixon, M. (1953) Biochem. J. 55, 170-171.

19. Coleman, R., and Hübscher, G. (1962), Biochim. Biophys. Acta 56, 479-490.

20. Smith, M. E., Sedgwick, B., Brindley, D. N., and Hübscher, G. (1967) Eur. J. Biochem. 3, 70-77.

21. van den Bosch, H., and Vagelos, P. R. (1970) Biochim. Biophys. Acta 218, 233-248.

22. Caras, I., and Shapiro, B. (1975) Biochim. Biophys. Acta 409, 201-211.

23. Johnston, J. M., and Bearden, J. H. (1962) Biochim. Biophys. Acta 56, 365-367.

24. Jimenez, J. M., and Johnston, J. M. (1976) Pediat. Res. 10, 767-769.

25. Bleasdale, J. E., Davis, C. S., and Agranoff, B. W. (1978) Biochim. Biophys. Acta, in press.

26. Jimenez, J. M., Schultz, M., MacDonald, P. C., and Johnston, J. M. (1974) Gynecol. Invest. 5, 245-251. 